\title{
Xi Jinping and His Thoughts on Socialism With Chinese Attributes
}

\author{
Li Yangkuo \\ Huaihua University \\ Tian Guang* \\ Huaihua University \\ (Corresponding Author)
}

\begin{abstract}
Socialism with Chinese Attributes has entered a new era with China's new historical development orientation. Confronted with the new situation at home and abroad, Xi Jinping has initiated some new concepts, ideas and strategies to lead the Chinese people to advance towards the great rejuvenation of the Chinese nation. His idea of the Chinese Dream depicts a dream of prosperity, national renewal, and happiness, injecting a new connotation and spirit of the times into the adherence to and development of socialism with Chinese Attributes. In the new journey of the new era, Xi Jinping proposed to facilitate the building of a community with a shared future for humankind, establishing a deep and close relationship between China and the world. This paper elaborates on the theoretical ideas and practical activities of Xi Jinping, leading the Chinese people to develop a great socialist culture in China and achieve the great rejuvenation of the Chinese nation. Xi Jinping Thoughts on Socialism with Chinese Attributes for a New Era summarizes the historical experience and the engine for China's future development.
\end{abstract}

Keywords: Xi Jinping thoughts, Chinese dream, socialism with Chinese attributes, shared future for humanity

\section{INTRODUCTION}

This paper summarizes Xi Jinping's thoughts on socialism with the Chinese attributes. China is the largest developing socialist country. The Communist Party of China (CPC) is the core leadership chosen by all Chinese people. All the achievements the Chinese people have made in the past century were under the leadership of the CPC. At noon on November 15, 2012, Xi Jinping met with more than 500 journalists from domestic and abroad, as General Secretary elected after the First Plenary Session of the 18th CPC Central Committee. According to Martin Jacques, author of When China Rules the World: The End of the Western World and the Birth of a New Global Order, Xi Jinping's presidency as General Secretary of the CPC Central Committee marked the beginning of a new era (Jacques et al., 2016). At the time, the effects of the 2008 global financial crisis were still being felt. After decades of development, China became the second-largest economy in 2010 and was critical to achieving socialist modernization. Some emerging countries have accelerated their ascension. The world landscape was undergoing a profound evolution. Xi outlined the mission of the new central leadership group as "three responsibilities": responsibility to the 
nation, responsibility to the people, and response to the Party. He stated that the people's aspiration for a better life is CPC's goal of struggle. Subsequently, Xi proposed "the Chinese Dream" to "realize the great rejuvenation of the Chinese nation." He spent his days and nights achieving the dream during the next seven years. Soon after he was elected General Secretary, Xi systematically reviewed the origins and evolution of socialism over the past five centuries. He summarized and shared the successes and failures of the political systems adopted by China with senior CPC cadres since modern times. It further demonstrates the significance of the path of socialism with Chinese Attributes (Han et al., 2020).

Since taking office as General Secretary, Xi Jinping has visited many revolutionary sites. He stressed that the rules of the Communist Party of China were formulated there at Xibaipo and that the Chinese government should never forget its original intention at all times on Jinggang Mountains. When visiting the site of the first National Congress of the Communist Party of China, Xi Jinping regarded it as the spiritual home of the Chinese Communists. When visiting Xiangshan Mountain, he said that the Chinese government should answer the new era with sobriety and determination as if taking a test. In 2017, Xi Jinping Thoughts on Socialism with Chinese Attributes for a New Era were formally established at the First Plenary Session of the 19th CPC Central Committee, when Xi was re-elected General Secretary of the CPC Central Committee. This concept has received worldwide attention. Xi Jinping was determined to lead the Chinese Communist Party, self-revolution with nearly 90 million members. He initiated the campaign to exercise complete and strict governance over the Party, accelerated the introduction of the Eight Rules, and presided over the formulation of The Norms Regarding Intra-Party Political Life in New Situation, and Regarding Regulations Intra-Party Supervision. Also, he directed four thematic education campaigns to "purify" the Party.

Xi Jinping has led an unprecedented "anti-corruption campaign" that has left no room for error. Between the 18th and 19th CPC National Congress, 440 party cadres above the provincial and ministerial levels were investigated and punished in the five years. Since the conclusion of the 19th CPC National Congress, the Central Commission for Discipline Inspection of the Communist Party of China and the National Supervisory Commission has investigated more than 100 cadres on file with the Department of Organization of the Communist Party of China and many provincial and ministerial-level officials were convicted. The Foreign Affairs website remarked that Xi Jinping leads the world's largest and most successful Marxist-Leninist organization and is determined to ensure that it sustains that status. The Sixth Plenary Session of the 18th CPC Central Committee in 2016 established Xi Jinping as the core of the CPC Central Committee and the core position of the Party. In March 2019, Xi Jinping met with Roberto Fico, the Italian Chamber of Deputies president. Fico asked Xi Jinping, "How did you feel when elected President of China?" Xi said: "It is a weighty responsibility to manage such a big country, and the work is very challenging. We will fully commit to the people and never fail them. We are willing to accomplish a state of 'no-self' and dedicate ourselves to the development of China."

\section{Reform and Socialist Modernization}

$\mathrm{Xi}$ Jinping pointed out that the Chinese government is closer to, more confident in and capable of achieving the great rejuvenation of the Chinese nation than at any other time in history. According to the blueprint of the 19th CPC National Congress, a moderately prosperous society will be achieved throughout China. Based on this, socialist modernization will be achieved by 2035 with 15 more years of hard work. Subsequently, with hard work for another 15 years, China will grow into a great modern socialist country by the middle of the 21st century. The leadership of China, with a strong sense of mission, is determined to deliver an answer that will satisfy the people. In the seventh year of Xi Jinping's leadership, China's economy exceeded 90 trillion yuan, ranking second. China is also the world's largest industrial country, the largest trader in goods, the largest foreign exchange reserve holder, the second-largest recipient of foreign direct investment, and the second-largest consumer of goods.

According to the National Bureau of Statistics of China and the World Bank, China's economy will grow by $8.5 \%$ in 2021 , while the global economy will grow by $5.6 \%$ in the same period. China has the world's most complete industrial chain, with the world's most significant production of more than 220 types of industrial products. It has the most extended high-speed rail network by mileage and has launched 
a probe to the moon's back. In 2021, there are 143 Chinese companies on the list of the world's top 500 companies, and for the first time, China topped the list. These achievements are the fruits of the hard work of the Chinese people and the result of the comprehensive and in-depth promotion of reform and opening up. The reform and opening up initiated by Deng Xiaoping in 1978 are regarded as a "social revolution," while Xi Jinping is determined to take this "revolution" to the end. After being elected general secretary in 2012, he visited Shenzhen, addressing that reform and opening-up is a game-changing move in making China what it is today. Stop or reverse reforms and opening up would only lead to a blind alley (Wang, 2008).

Under Xi Jinping's leadership, the reform indicates a new era focusing on cracking the barriers of solidified interests. The reform is more oriented to top-level design, emphasizing systemic, holistic and synergistic development. In 2013, a seven-year timetable for comprehensively deepening the reform was set by the Third Plenary Session of the 18th CPC Central Committee, and a large-scale reform program was unveiled. Xi Jinping defined the overall objectives of comprehensively deepening reform as developing and improving the system of socialism with Chinese Attributes and modernizing China's system and capacity for governance. Xi Jinping stressed that the Chinese government should be results-oriented and pioneering, that empty talk is harmful to the nation, while practical jobs can help it thrive. The Chinese government must start with specific things and ensure their implementation. These remarks may help outsiders understand why the marvelous "China speed" and "China projects" are frequently produced in the new era.

Since 2012, Xi Jinping has visited various parts of China, going deep into the grassroots to investigate and guide economic and social development and reform and opening up, visiting factories, villages, communities, ports, schools, and barracks. Sometimes, he had to reach high mountains several thousand meters above sea level. Sometimes, to get to a village, he got off the plane, changed to a train, and took a bus. He sometimes pulled up his trouser legs and held up an umbrella to communicate with the people when it was raining during the visit. A few years ago, he launched the strategy for developing the Yangtze River Economic Belt. In 2019, he visited Henan Province and proposed a strategy for ecological protection and high-quality development of the Yellow River Basin. The two river basins of China present new energy in the new era. Xi Jinping designed a more market-oriented reform program for state-owned enterprises and encouraged private companies to take their stakes. He remarked that private businesses and entrepreneurs are also inseparable country members at the symposium on private enterprises. One of the most frequently mentioned concepts by Xi Jinping is "innovation." Xi believes that begging alms will not get the core and critical technology.

In 2019, Xi Jinping visited Dunhuang and gave new instructions on preserving and developing culture. $\mathrm{He}$ frequently stated that cultural confidence is a more fundamental, broader and deeper confidence. He has led the reform of Party and state institutions, working to create more efficient and modern government agencies. In the past few years, the Chinese government has cut administrative approvals by a third. Online approvals and "one-stop" services have been implemented in many places, so enterprises do not need to get their documents sealed for months. Xi Jinping advocates comprehensive law-based governance. He stressed the importance of understanding that the negative impact of a misjudged case can destroy the positive image accumulated by 99 fair decisions. The reform of the justice system is being carried out by exercising judicial and procuratorial powers independently and impartially according to the law, improving the mechanism for the operation of judicial power, and perfecting the judicial protection of human rights. In terms of ecological environment, he launched the famous concept of temperate waters and lush mountains. Xi Jinping personally delivered the instrument of ratification of the Paris Agreement on climate change to the UN Secretary-General. The effectiveness of "Green China" has been recognized and praised worldwide. Many cities have seen significant reductions in pollution. Xi proposed to promote the synergistic development of the Beijing-Tianjin-Hebei region and create the Xiong'an New Area. The China (Shanghai) Pilot Free Trade Zone, established in 2013, has been a success, and now the number of pilot free trade zones has grown to 18, with the entire area of Hainan Island to be built as a pilot free trade zone. Xi also announced the further opening of industries ranging from banking to automobiles. 
Since the advent of the new era, China's investment environment has been continuously improving. According to the World Bank's report Doing Business 2019: Training for Reform, China jumped from 78th to 46th place in the Doing Business rankings. The Chinese market is growing in size. Data show that it is closing in on becoming the world's largest consumer market. China's Ministry of Commerce in August 2018 announced that more than 24,000 new foreign-invested enterprises were established in China in the first seven months of that year. The actual foreign investment exceeded RMB 530 billion, up 7.3\% yearly. Xi Jinping attended the world's first import-themed expo in Shanghai, where he referred to "openness" 52 times in his 35-minute speech. The turnover of the Expo was encouraging. More businesses from different countries signed up for the second China International Import Expo. In 2018, Xi Jinping revisited Shenzhen when it celebrated its 40th anniversary of reform and opening-up to tell the world that China will not stop its reform and opening-up. He addressed that China will undoubtedly deliver a bigger miracle that draws worldwide attention (Yang et al., 2018).

\section{Serve the People Is the Only Purpose of Socialism}

Every day in 2019, 16,500 new enterprises were registered in China, and about 40,000 people were newly employed in urban areas. Over the past seven years, more than 80 million new jobs have been created in China's cities and towns, which is equivalent to the population of Germany. Xi Jinping said, "Employment is the most important livelihood." The emerging economy formats, such as e-commerce, have resulted in outstanding jobs. Xi Jinping has been highly encouraging and encouraging in this regard. He once came across a group of couriers in a Beijing hutong and expressed his condolences for their hard work. China now has the world's largest courier industry, with more than 3 million couriers. In his New Year's greeting for 2018, Xi indicates that he was aware of the people's biggest concerns, such as education, employment, income, social security, healthcare, old-age security, housing and the environment. Since he became General Secretary, Xi Jinping has been with the people every year at the Chinese New Year. Xi visited the struggling workers in the border town in the cold of $-30^{\circ} \mathrm{C}$. He also delivered New Year's goods to the villagers at his own expense, made Ciba with the people, and stuck the Chinese character “福” on the doors of the residents' houses. He expressed concern about whether poor farmers have enough food to eat, have medical care coverage, and whether their children can go to school. The principal contradiction of Chinese society has been transformed into the contradiction between the people's growing need for a better life and unbalanced and insufficient development (Xu \& Zhang, 2018). The significant assertion made by Xi Jinping in the report of the 19th CPC National Congress embodies his scientific and accurate judgment and grasp of the national conditions and people's opinions.

$\mathrm{Xi}$ Jinping repeatedly stated that the purpose of the CCP is to serve the people wholeheartedly (Qu, 2019). It also reflects Xi Jinping's personal experience and will. He went to the poor countryside in Shaanxi Province before he was 16 years old to settle in the communes and lived in labor for seven years. He wanted most for his fellow villagers to have a full meat meal. He said he came from a poverty-stricken village, and he well understood the people's hardships. For a while, housing prices in China were soaring. Xi Jinping warned that houses are for the living, not for speculation. He added that cities could not be filled with highrise buildings and dirty shantytowns on the other side. In 2018, China's urban areas' per capita housing floor area reached 39 square meters, up 3.7 times from 8.3 square meters in 1949. Housing security efforts have enabled about 200 million people in need to live in peace.

Xi Jinping has taken people's affairs very seriously. During his visits to the grassroots, he repeatedly inspected the toilets of ordinary people's houses and instructed them to sort garbage properly. During a visit to a village in Henan Province, he proposed modernizing and facilitating living facilities to take a hot bath. He also gave instructions on the high incidence of myopia among students. China's social security system was a complete blank a few decades ago. By 2019, China has achieved full basic medical insurance and pension insurance coverage for more than 900 million people, forming the world's largest social security network. In 2013, Xi Jinping proposed the concept of "targeted poverty alleviation" to thoroughly eliminate absolute rural poverty under the current standards by 2020 . He set the goal of eliminating absolute poverty in rural areas by 2020 under current standards, ten years ahead of the time set by the United Nations to eradicate absolute poverty globally. More than 82 million people have been lifted out of poverty in seven 
years. Xi Jinping said, "the Chinese government will have brought to an end, once and for all, the extreme poverty that has shackled the Chinese nation for millennia in this generation (Chen, 2020)."

According to Kishore Mahbubani, a professor at the National University of Singapore, the most remarkable achievement of China is the substantial improvement in the living standards of Chinese people $(\mathrm{Xu}, 2018)$. Even at its best time in Chinese civilization, many lower classes still lived in poverty. Even those with low incomes enjoy access to better food, accommodation, education, health care, and employment in today's China. Xi Jinping is living up to his promise: "Love the people as I love my parents." At the first session of the 13th National People's Congress of China in March 2018, Xi Jinping was reelected president, winning the unanimous support of nearly 3,000 NPC members.

At the 19th CPC National Congress, the strategic arrangement was proposed to secure a decisive victory in building a moderately prosperous society and achieving China's second centenary goal in two stages. Based on this, Xi Jinping explicitly outlined the objectives and tasks of implementing the rural revitalization strategy. Rural revitalization strategy insists on prioritizing the development of agriculture and rural areas. Its objectives are to establish and improve the institutional mechanism and policy system for integrated development of urban and rural areas and accelerate the modernization of agriculture and rural areas by the general requirements of prosperous industry, pleasant ecology, civilized countryside, effective governance and wealthy living. The Chinese government should start from seven aspects to implement the rural revitalization strategy.

First, the Chinese government should reshape the relationship between urban and rural areas and take the integrated development of urban and rural areas. Secondly, the Chinese government should consolidate and improve the basic rural management system and take the path of shared prosperity. Thirdly, the Chinese government should deepen the structural reform on the supply side of agriculture and take the road of flourishing agriculture with quality. Fourthly, the Chinese government should adhere to the harmonious coexistence of man and nature and take the road of green development in the countryside. Fifthly, the Chinese government should inherit, develop and enhance the farming civilization, and take the road of rural cultural prosperity. Sixthly, the Chinese government should innovate the rural governance system and take the road of good governance in the countryside. Seventhly, the Chinese government should do its best for targeted poverty elimination and take the road of poverty reduction with Chinese Attributes.

From March 29 to April 1, 2020, Xi Jinping stressed during his visit to Zhejiang province that building China into a modernized socialist country in all aspects requires both urban modernization and agricultural and rural modernization. The Chinese government should make more significant efforts to promote rural revitalization throughout the countryside, advance and strengthen the rural economy. To advance and strengthen the rural rule of law, rural culture, rural governance, rural ecology, and party construction enable villagers to live a better life. On September 18, 2020, Xi Jinping stressed during an inspection tour in Hunan province to adhere to the prioritization of agriculture and rural areas and drive the implementation of the rural revitalization strategy. He added that the departments concerned should guarantee food security, steadily raise grain output, implement the responsibility system for arable land protection, cultivate more high-standard farmland, and curb illegal arable land appropriation.

The government should deepen agricultural and rural reforms to activate the endogenous power of rural revitalization. It should also establish a sound long-term mechanism to avoid falling back into poverty and conduct an in-depth study to promote the compelling connection between comprehensive poverty elimination and rural revitalization $(\mathrm{Hu}, 2021)$. Moreover, the government should deepen the structural reform on the supply side of agriculture, cultivate and grow profitable industries according to local conditions, and promote the integrated development of primary, secondary and tertiary industries in rural areas. Also, it is necessary to implement the principle of insisting on responsibility, support, policies and supervision even after poverty is eliminated. Since the introduction of the rural revitalization strategy, Xi Jinping has visited and inspected various parts of China, thoroughly investigating the situation of poor villages and continuously exploring and practicing, putting forward the critical idea of targeted poverty alleviation. He commanded the CPC and the whole country to win the battle against poverty, laying a solid foundation for further rural revitalization and setting a new milestone in Chinese history. 
Removing the label of extreme poverty is not the end but the beginning of a new life and a new journey. In the grand gathering held in Beijing to mark the country's accomplishments in poverty alleviation and honor its model poverty fighters, Xi Jinping emphasized that the Chinese have no reason to be complacent and rest on their laurels. They must move forward, make further efforts and continue the struggle, and inspire the cadres and masses to make new achievements in building a modern socialist country in all aspects and realizing China's second centenary goal. Also, at the grand gathering, Xi Jinping pointed out that rural revitalization is a significant task to rejuvenate the Chinese nation (Zhang, 2021).

According to the new requirements arising from the new development concept and patterns in the new era, the Communist Party of China should prioritize the three issues of agriculture, the countryside and farmers. It should adhere to the prioritization of agriculture and rural areas, follow the road of socialist rural revitalization with Chinese Attributes, and continue its efforts to narrow the gap between urban and rural areas. In this way, the low-income population and the less developed regions can share the fruits of development and not fall behind in the modernization process but catch up ( $\mathrm{Li}, 2021)$. In 2021, Xi Jinping repeatedly researched and spoke about rural revitalization, emphasizing the comprehensive implementation of the rural revitalization strategy. There will be no national rejuvenation without a thriving countrysideXi Jinping's affirmation of the importance of the rural revitalization strategy.

\section{People-Centered Law-Based Governance}

As China moves into a new era and people's living standards continue to rise, people's demand for lawbased governance grows. The CPC must continue to improve law-based governance to meet the growing needs of the people for a better life. Xi stated the need to actively advance legislation in national security, science and technology innovation, public health, biosecurity, ecological civilization, risk prevention, and foreign-related law-based governance. The Chinese government should improve the legal system urgently needed for national governance and the legal system necessary to meet people's growing demand for a better life (Zhang, 2021).

In recent years, Xi Jinping has positioned, layout and practiced the law-based governance from a global and strategic perspective of adhering to and developing socialism with Chinese Attributes. He creatively introduced new concepts, ideas, and strategies on comprehensive law-based governance, resulting in $\mathrm{Xi}$ Jinping's Thoughts on the Rule of Law. Xi emphasized that since the people make up the broadest and most profound foundation for comprehensively advancing law-based governance, the Chinese government must ensure that their interests and wishes are reflected, their rights are protected, and their well-being enhanced. The Chinese government should strengthen legislation in key areas, including public health and ecological civilization, all of which are of vital interest to the people (Yang, 2021).

Given that China is a socialist country where the people are the masters, the Chinese government must always prioritize the interests of the people and safeguard the principal status of the people, which is the primary embodiment of the people-centered nature of Xi Jinping Thoughts on the Rule of Law (He, 2021). Xi Jinping attaches great importance to the critical role of law in governing the country, permanently adheres to the people as the center, and clarifies the central position of the people in law-based governance. People's procuratorates and public security organs at all levels adhere to Xi Jinping Thoughts on Socialism with Chinese Attributes for a New Era as a guide, fully implement Xi Jinping Thoughts on the Rule of Law, and adhere to the principle of division of labor, cooperation and mutual restraint. Moreover, they should continue to deepen the investigation supervision and cooperation mechanism, punish all kinds of crimes under the law, and provide a solid law-based guarantee to maintain social stability, promote social fairness and justice, and protect people's happiness.

The practical actions of public security officers practiced Xi Jinping Thoughts on the Rule of Law. In January 2021, Xi Jinping gave essential instructions on celebrating the 100th anniversary of the founding of the Communist Party of China by building a safer China, enhancing law-based governance in China, securing people's happiness, and enhancing national security and social stability (Zhu et al., 2021). It has sparked a warm reaction in all sectors of society, especially in the political and legal system. Xi underlined that 2021 is the start of the "14th Five-Year Plan", and political and legal organs should conscientiously implement the instructions of the Fifth Plenary Session of the 19th CPC Central Committee and the central 
work conference the rule of law. They should also pay more attention to the rule of law and effectively promote high-quality political and legal work development.

Xi Jinping pointed out that the public security forces are the most sacrificed during peacetime, with significant contributions. The Chinese government should extend exceptional care to this particular team, with political care, work support and welfare, and fully implement measures to treat the police preferably at all times. According to statistics, since the founding of the People's s Republic of China, more than 16,000 police officers have lost their lives in the line of duty, of whom more than 3,700 were awarded as martyrs. Three thousand seven hundred seventy-three police officers died on duty in the past ten years, and more than 50,000 police officers were injured. He stated, "Over the years, I was deeply touched when learning about the heartfelt needs of the public security officers and heartbroken when I heard the public security officers sacrificed their lives in the frontline. Xi Jinping's loving care has greatly inspired the people's police forces to better the vital mission entrusted by the Communist Party of China and the people. The efforts of the public security officers demonstrate the people-oriented thoughts on the rule of law, and Xi Jinping's condolences on these officers manifest his emphasis on the comprehensive rule of law. It accurately depicts Xi Jinping's thoughts on the Rule of Law.

\section{Ecological Civilization and Beautiful China}

Since the 18th CPC National Congress, the CPC Central Committee has incorporated the construction of ecological civilization into the overall layout of socialism with Chinese Attributes. In advancing the construction of ecological civilization, it has developed the Xi Jinping Thoughts on Ecological Civilization. This thoughts has facilitated understanding the laws of nature and human social development (Li, 2021). On October 18, 2017, Xi Jinping emphasized in the 19th CPC National Congress report that man and nature are a community of life. Humans must respect nature, conform to nature, and protect nature. The construction of ecological civilization is credited to the current generation and benefits thousands of years. The Chinese government should firmly establish the socialist concept of ecological civilization, promote the formation of a new pattern of modernization for the harmonious development of man and nature, and make this generation's efforts to protect the ecological environment!

The water quality of the Yangtze River is getting better and better. On September 18, 2019, Xi Jinping presided over a symposium on the Yellow River basin's ecological protection and high-quality development in Henan Province and delivered his keynote speech. He explicitly proposed that the protection of the Yellow River is critical to the great rejuvenation and sustainable development of the Chinese nation (Zhang, 2021). Subsequently, Xi hosted the symposium on promoting the development of the Yangtze River Economic Belt in Chongqing, the symposium on further promoting the development of the Yangtze River Economic Belt in Wuhan and the symposium on comprehensively promoting the development of the Yangtze River Economic Belt in Nanjing. These symposiums were designated to promote the 11 provinces and cities along the Yangtze River to make concerted efforts to control pollution and repair ecosystems. He stressed the need to take care of global protection, not engage in large-scale development, and take a new path of ecological priority and green development.

Xi draws a long-term picture in his mind, and he has continued to promote ecological development. He has also been committed to deploying the development of the Yangtze River Belt with general protection without large-scale development works, promoting ecological protection and high-quality development in the Yellow River Basin, removing illegal villas and repairing ecological damage in the northern Qinling Mountains in Shaanxi Province, and accelerating the construction of nature reserve systems centered on national parks. During his visit to Beijing and Hebei from January 18 to 19, 2021, he pointed out that China will continuously promote sustainable development and fully implement the UN 2030 Agenda for Sustainable Development. The Chinese government will accelerate the construction of ecological civilization, adjust and optimize the industrial and energy structures, and promote a green and low-carbon production and lifestyle. China will strive to reach peak CO2 emissions by 2030 and achieve carbon neutrality by 2060 .

On January 25, 2021, at the World Economic Forum Virtual Event of the Davos Agenda, Xi Jinping emphasized that China should uphold the concept that lucid waters and lush mountains are invaluable assets

Journal of Applied Business and Economics Vol. 24(1) 2022155 
and prioritize ecosystem conservation for an environmentally friendly development model (Han, 2020). During his visit to Qinghai from June 7 to 9, 2021, Xi Jinping proposed that China should respect, respond to, and protect nature and build a green home together in the face of the fragile ecological environment. In the face of the severe challenges, climate change poses to human survival and development, the Chinese government should take up the responsibility and work together to find a way to harmoniously coexist with nature (Wang et al., 2021).

At the same time, the concept of "a community with a shared future for mankind" proposed by President Xi Jinping has become increasingly influential in the international community. The concept of "a community with a shared future for mankind" aims to give proper consideration to the legitimate concerns of other countries while pursuing national interests and promoting the joint development of all countries in the pursuit of national development. Humanity has only one Earth, and all countries share one world, and we need to promote the awareness of a community with a shared future for humankind. Humans should respect each other, non-human life, and inanimate objects (Liao et al., 2021).

\section{Fight for a Great Dream and the Power of China}

The Chinese word 斗争 (douzheng, means struggle) appeared nearly 60 times in his speech at the Party School of the Central Committee of the Communist Party of China (National Academy of Governance) in September 2019. When Xi Jinping delivered the speech at the opening ceremony of a training program for younger officials, he stressed that the rejuvenation of the Chinese nation would not be easily achieved, so the Chinese government should struggle to achieve the great dream. Xi Jinping's sense of struggle can be traced back to when he went to the countryside in Liangjiahe and became a production team member. The hardships of that time have sharpened him into an unyielding and courageous person. Xi Jinping said that the risks and tests facing the Chinese government would get more and more complicated, to the extent that it may encounter unimaginable storms (Yan, 2019).

$\mathrm{Xi}$ Jinping viewed the fight against corruption as a life-and-death duel. This fight started with corruption and anti-corruption opposing in a stalemate. Then an overwhelming anti-corruption situation began to take shape and was then developed, and finally, a victory was achieved. He led the whole Party and the whole nation to cope with the economic downturn challenges turn with his sobriety and wisdom. He launched three significant campaigns to guard against and defuse significant risks, eradicate poverty in a targeted manner, and prevent and control pollution. Moreover, he proposed strategies such as the "new normal of economic development," "new development concept," and "supply-side structural reform" to promote high-quality economic development (Lan, 2021).

At the time of the China-US economic and trade frictions, China does not want a trade war, but it is not afraid of one and will fight one if necessary under the deployment of Xi Jinping (Guan, 2019). He met with President Trump in Buenos Aires and Osaka to take a significant step forward in resolving economic and trade frictions between the two countries. On the issue of Hong Kong, Xi pointed out that if Hong Kong were to fall into the whirlpool of "pan-politicization," artificial confrontation and rivalry would be created. It would serve no useful purpose and seriously hamper economic growth and social development. When he met with the new Chief Executive of the Macao SAR, he pointed out that the "one country, two systems" policy has proved feasible, workable, and supports the people. He requested an appropriate policy of "two systems" for Taiwan to advance the peaceful resolution of the Taiwan question for the complete reunification of China. The Chinese government makes no promise to renounce force and reserve the option of taking all necessary means. It does not target compatriots in Taiwan, but the interference of external forces and the minimal number of "Taiwan independence" separatists and their activities (Wu, 2019).

Xi Jinping has taken a bold step to reform the national defense and military, firmly establishing combat effectiveness as the only fundamental standard. It has become one of the military's missions to protect China's interests abroad in the new era. Amid unrest in West Asia and North Africa, Xi Jinping directed the evacuation of overseas Chinese. The movie based on it set a record at the Chinese box office. In a recent article, Foreign Affairs magazine wrote, "He is among the more assertive when defending interests." According to $\mathrm{Xi}$, the various struggles the Chinese government face are not short-term but long-term and must accompany us for at least the entire process of achieving the second-century goal. He led the ruling 
team with a deep insight into the complexities and changes of the outside world and a clear understanding that China is still the world's largest developing country. In May 2019, Xi Jinping came to Yudu County in Jiangxi Province, the starting point of the Central Red Army's Long March, and called on people to walk solidly on the new Long March. In the 1930s, the Chinese Workers' and Peasants' Red Army fought a 25,000-mile march against harsh nature, heavy enemy siege and the Party's erroneous line, and eventually achieved revolutionary victory at great sacrifice. In the eyes of the Chinese Communists, all the hard work was done to achieve their glorious and sacred purpose.

At the end of 2019, a sudden epidemic swept the world. China's central government quickly decreed the city's lockdown, effectively curbing its spread and winning the initiative. In this battle, the people's power was united. Xi Jinping pointed out that the Chinese people empowered the government to overcome the epidemic. In the darkest moments of the epidemic, countless ordinary people stepped forward, and the love from the ordinary people lit up the land. In the face of the COVID-19 pandemic, Xi Jinping repeatedly emphasized the need to be determined to fight and win the battle against the epidemic by mobilizing all resources; and blocking the spread of the virus (Wang et al., 2020). It answers the questions of who and how to fight against the COVID-19 pandemic and what to do, fully reflecting Xi Jinping's high positioning, accurate grasp, and strong determination to prevent and control the epidemic and his superior strategic wisdom (Wang, 2020).

In the prevention and control of the epidemic, Xi Jinping took the overall picture and carried out timely and effective social mobilization, unleashing the governance effectiveness of China's socialist system. The Chinese have made a significant contribution to the world's public health, fully demonstrating the institutional advantages of socialism with Chinese Attributes and Chinese wisdom in building a community with a shared future for humankind (Wang, 2021). Xi Jinping pointed out that China should strengthen strategic, systematic and forward-looking research and planning, cultivate new opportunities in crises, open up new situations in changes, and adjust its strategies of struggle in time according to the changes in the situation. It is essential to be mentally prepared and ready to work for a prolonged period to deal with changes in the external environment. In a sense, it will be a protracted battle (Ruan, 2021).

In July 2021, some provinces and regions in China were flooded in emergencies. Xi Jinping gave essential instructions on flood control and disaster relief work. Xi stressed that authorities must always put people's safety and property first and take the lead in fighting the floods. He ordered authorities to organize flood prevention and disaster relief forces promptly, adequately accommodate those affected, strictly prevent secondary disasters, and minimize casualties and property losses. Party committees and governments at all levels earnestly implemented the spirit of Xi Jinping's important instructions. In the spirit of extreme responsibility for the people, they assumed the political responsibility to promote the development of an area, ensure its security, and fully exercise the principal responsibility for flood control and disaster relief. They adopted more vigorous measures to strengthen organizational leadership and responsibility for the implementation and effectively undertake the work of flood control and disaster relief, resolutely to do their duty of guarding the land. The CPC members and cadres moved towards the flood, the people's soldiers came to the rescue. The firefighters made every effort, the people in the affected areas joined together, the volunteers stood firm on the front line, and countless people expressed their concern. In the face of the grim flood control situation, the entire country quickly gathered a potent force for flood control and disaster relief.

\section{Community With a Shared Future for Mankind}

In 2014, the number of Chinese outbound travelers exceeded 100 million for the first time, and China's foreign direct investment exceeded $\$ 120$ billion, bringing two-way direct investment closer to balance for the first time. Thousands of Chinese people are working, studying, and living worldwide. It has become a joint statement in the news that China is moving closer to the world's center stage. The relationship between China and the world in the new era is a significant issue facing Chinese leaders (Liu, 2019). Nearly 20 years ago, when Xi Jinping was the governor of Fujian Province, he promoted a demonstration project of mycorrhiza and upland rice cultivation technology in the Eastern Highlands Province of Papua New Guinea. Mycorrhizal projects with sand control, livestock rising, power generation, and new material development 
have spread to more than 100 countries, making it possible for developing countries in Africa, Asia, and the South Pacific to alleviate poverty.

In November 2018, during his visit to Papua New Guinea, Xi Jinping witnessed the official signing of a package of agreements on China's assistance to PNG for mycorrhiza and upland rice technology. This event reflects Xi's desire and thinking about the international relations he wants to build. There should be mutual respect, fairness and justice, and win-win cooperation between countries as he sees it. In March 2013, during his first trip to Moscow after assuming the presidency, Xi Jinping elaborated on the concept of a community with a shared future for humankind and new types of international relations at the Moscow Institute of International Relations (Liu, 2021). Two years later, Xi Jinping delivered his first speech from the UN rostrum, comprehensively illustrating the primary meaning of a community with a shared future for humankind. Later, he further elaborated on building a world free from fear and universally safe, free from poverty and universally prosperous, free from closed doors and open and inclusive, clean and beautiful in all its landscapes (Chen, 2019)." The Belt and Road Initiative, proposed by Xi Jinping, is a platform for facilitating a community with a shared future for humankind. This ambitious idea connects continents and oceans with trade and investment.

Contrary to the "misgivings" of some Westerners, its aim is simply to "integrate more countries and regions into economic globalization, and to work together to create a mutually beneficial and win-win path." By the end of July this year, China has signed 194 cooperation documents with 136 countries and 30 international organizations to construct the Belt and Road. According to a study released by the World Bank in June, the full implementation of The Belt and Road Initiative could lift 32 million people out of moderate poverty, increase global trade by $6.2 \%$, increase trade of economies along the route by $9.7 \%$, and increase global income by $2.9 \%$. "Diplomacy as host" has become a shining "business card" in the new era. China has hosted various events, from APEC in Beijing, the Fourth Summit of the Conference on Interaction and Confidence-Building Measures in Shanghai China, the G20 Summit in Hangzhou, the BRICS Leaders' Meeting in Xiamen, the SCO Summit in Qingdao and the Boao Forum for Asia, the two Belt and Road Summits on International Cooperation, the Beijing Summit of the Forum on China-Africa Cooperation, the International Horticultural Exhibition and the Conference on Dialogue of Asian Civilizations. It marked China's emergence as a hub for discussing global governance and development. In presiding over these events, Xi Jinping told, in a personal way, the story of how China's development has allowed countries to "take a free ride" in a personal and engaging way. He explained the true meaning of a shared future for humankind. He proposed to accelerate the innovation and perfection of the global governance system based on extended consultation, joint contribution, and shared benefits ( $\mathrm{Su}, 2019)$.

China has become a vital force in addressing global and regional hotspots ranging from climate change, anti-terrorism, nuclear proliferation, the gap between rich and poor, fair trade and peacekeeping in war. Many Chinese have served as the principal heads of international organizations such as the Food and Agriculture Organization of the United Nations, contributing more Chinese wisdom to promote global governance on related issues. The Chinese currency, Renminbi, was eligible for joining the International Monetary Fund's Special Drawing Rights (SDR) currency basket. The Asian Infrastructure Investment Bank and the Silk Road Fund were also created.

In 2019, China became the second-largest contributor to the United Nations after the United States. It is also one of the major contributors to UN peacekeeping operations and the most significant contributor of troops among the Security Council's permanent members. The China-UN Peace and Development Fund established by China for ten years with one billion USD was officially launched in 2016. China has contributed more than 30 percent to world economic growth. It has also steadily resolved the subsistence problems of more than one billion people and contributed more than 70 percent to global poverty reduction, which the World Bank has called "one of the most extraordinary events in human history. China's development experience and model have expanded avenues of modernization for developing countries (Zheng, 2021). Xi Jinping said that the Communist Party of China has always made its mission to make new and more outstanding contributions to humanity (Zhang \& Kong, 2018). Contributing to humanity is the vision of the Communists. 


\section{CONCLUSION}

In leading the Chinese people to realize the Chinese Dream, Xi Jinping, with profound insight, keen judgment and strategic determination as a Marxist statesman and theorist, has proposed some groundbreaking new ideas, thoughts and strategies. Xi Jinping Thoughts on Socialism with Chinese Attributes for a New Era, which originates from and guides practice, contains rich connotations and encompasses all aspects of the economy, politics, ecological civilization, national defense and military construction.

The core of Xi Jinping's theory of socialism with Chinese Attributes is to adhere to the people's desire for a better life as the goal of struggle, to make a better life for the people as the starting and ending point of all work, and to always speak for the people, to stand up for the people. It fully embodies the concept of governing for the people, the mission of working for the happiness of the Chinese people and the rejuvenation of the Chinese nation, and the value of pursuing the people first.

Xi Jinping's approach to governance has a strong contemporary flavor and practical relevance. He has insight into the times, grasps the trend of the times, leads the trend of the times from the forefront of human development, actively explores the significant issues related to the future and destiny of humankind, and contributes Chinese wisdom and Chinese solutions to the global challenges facing the world today and to the common problems facing humankind. The entry of socialism with Chinese Attributes into the new era is the fruit of the epochal changes that have taken place under Xi Jinping's outstanding leadership and the result of the long and ongoing struggle of the Chinese people.

\section{REFERENCES}

Chen, S.J. (2019). A study of the similarities and differences between Chinese and Western harmonious spirit and its cultural value to constructing a community with a shared future for humankind. Shanghai Jiao Tong University. DOI: 10.27307/d.cnki.gsjtu.2019.000083

Chen, X.H. (2020). A better life for all Chinese people. Beijing Observation, 11, 32-33.

Guan, M.W. (2019). The Historical Thoughts and Future Questions Behind the U.S.-China Economic and Trade Friction. Guangming Daily, 2019-06-03(001). DOI: 10.28273/n.cnki.ngmrb.2019.003538

Han, H. (2020). Study on the practice of Xi Jinping Thoughts on Ecological Civilization in Guizhou. Guizhou Social Sciences, 11, 40-47. DOI: 10.13713/j.cnki.cssci.2020.11.005

Han, H.T., \& Xie, J.Y. (2020). On the scientific connotation of people's aspiration for a better life. Journal of Luoyang Institute of Science and Technology (Social Science Edition), 35(02), 81-86.

He, H.B. (2021). The People-centered Nature of Xi Jinping's Thoughts on the Rule of Law and Its Theoretical Value. Probe, 6, 1-16. DOI: 10.16501/j.cnki.50-1019/d.2021.06.001

$\mathrm{Hu}$, S.Y. (2021). Continuously enhance the people's sense of achievement, happiness and security--Study the spirit of Xi Jinping's important speech during his visit to Hunan. Xinxiang Review, 4, 33-34.

Jacques, M., Sun, Y.N., Zhang, L., \& Liu, Q. (2016). When China Rules the World: The end of the western world and the birth of a new global order. CITIC Press Group.

Lan, L.Z. (2021). Comprehensive, strict governance of the Communist Party is a great self-revolution. China Discipline Inspection and Supervision News, 2021-11-09(001).

DOI:10.28423/n.cnki.njjjc.2021.005232

Li, S.H. (2021). A multi-dimensional reflection on the significance of achieving a complete victory in the battle against poverty. Journal of Southern China, 8, 12-14.

Li, Z.S. (2021). Upholding the concept of a community with a shared future for humankind and working together to build a beautiful world where people and nature coexist in harmony-Keynote speech at the Guiyang International Forum on Ecological Civilization in 2021. Ecological Civilization in China, 4, 6-9.

Liao, L.M., \& Dai, X.L. (2021). The 11th Plenary Session of the 10th CPC Guiyang Municipal Committee was held. Guiyang Daily, 2021-08-25(001). DOI:10.28295/n.cnki.ngyrb.2021.003334

Liu, J.F. (2019). The dramatic changes in China's relations with the world since the reform and opening up. Study Times, 2019-01-28(001). DOI: 10.38216/n.cnki.nxxsb.2019.000664 
Liu, L.M. (2021). An exploration of the idea of building a new type of international relations with the concept of "building a community with a shared future for mankind." Academic Journal of Jinyang, 2, 87-94. DOI: 10.16392/j.cnki.14-1057/c.2021.02.012

Qu, Q.S. (2019). The original intention and mission of the Chinese Communists. Current Affairs Report (Study by Party Committee Central Group), 4, 20-42.

Ruan, Z.Z. (2021). The Significance of Xi Jinping's Thoughts on Diplomacy from the Perspective of Uniting Against the Epidemic. International Studies, 1, 11-28+124-125.

$\mathrm{Su}, \mathrm{C} . \mathrm{D}$. (2019). Adhering to the concept of global governance of extensive consultation, joint contribution and shared benefits. People's Weekly, 6, 58-59.

Wang, D.J. (2018). The critical move to determine the fate of contemporary China is reform and opening up. Party Building, pp. 11-13.

Wang, S.Z., \& Dong, G.L. (2021). Theoretical Perceptions and Practical Directions of Xi Jinping Thoughts on Ecological Civilization. The Party Building and Ideological Education in Schools, 22, 4-6. DOI: 10.19865/j.cnki.xxdj.2021.22.001

Wang, X.D., Zhang, Y., \& Qian, Y.B. (2020). Gathering an indestructible and powerful force. People's Daily, 2020-09-08(001). DOI: 10.28655/n.cnki.nrmrb.2020.008744

Wang, X.Y. (2021). Analysis of Xi Jinping's Important Discourse on Social Mobilization against the Epidemic. Journal of Chongqing University of Science and Technology (Social Sciences Edition), 3, 13-17. DOI: 10.19406/j.cnki.cqkjxyxbskb.2021.03.004

Wang, Y. (2020). Carrying forward the tremendous anti-epidemic spirit and highlighting the advantages of the socialist system with Chinese Attributes. Teaching and Research, 12, 5-14.

Wang, Y.K. (2008). There is no way out of stagnation and regression-Review of "The Road to PowerChina's Reform in 30 Years." Hainan Today Magazine, pp. 51-52.

Wu, Y.M. (2019). "China must be reunified, and it will be reunified" - On the 40th anniversary of the publication of Message to Compatriots in Taiwan. Taisheng, 3, 49.

$\mathrm{Xu}, \mathrm{H}$. (2018). Interview with Kishore Mahbubani, Professor at the School of Public Policy, National University of Singapore - China's success is critical worldwide. China Report, 7, 2.

Xu, S.H., \& Zhang, Z. (2018). On the triple logic of transforming the central social contradiction of socialism with Chinese Attributes in the new era. Journal of the University of Shanghai for Science and Technology (Social Science), 40(03), 246-252.

Yan, X.F. (2019). Strive to write a newer and more beautiful chapter of the times. PLA Daily, 2019-1011(007). DOI: 10.28409/n.cnki.njfjb.2019.006107

Yang, J. (2021). Adhere to the people as the center and solidly carry out local legislative work in the new era. Shandong NPC Work, 9, 49-50.

Yang, S., \& Xin, W. (2018). China's reform and opening-up will never stop. Xinxiang Review, 23, 9-10.

Zhang, J.Y. (2021). Making a compelling connection between poverty eradication and rural revitalization. New Long March (Party Building Edition), 4, 30-31.

Zhang, Y., \& Kong, X.F. (2018). On the Global Role of the Communist Party of China. Party Building Research, 8, 46-48.

Zhang, Y. (2021). Adhering to the leadership of party building and strengthening integrated innovation to build a new pattern of green and high-quality development in the Yellow River Basin. Rural Work Newsletter, 16, 33-35.

Zhang, Y.F. (2021). Xi Jinping's "people-centered" rule of law concept and the dual orientation of the law-based state. ECUPL Journal, 24(06), 116-129.

Zheng, Y.N. (2021). The Chinese Model Expands the Path to Modernization for Developing Countries. Special Zone Economy, 7, 9-10.

Zhu, Z.X., \& Liu, J.Q. (2021). Study and Implement Xi Jinping's Thoughts on the Rule of Law and Promote the Integrated Construction of the Criminal Rule of Law - Review of the First Seminar on The Constitution and the Construction of the Rule of Law in Criminal Enforcement. Tianjin Legal Science, 37(01), 73-80. 